\title{
FOOD AND ANTHROPOLOGY \\ in the Early Works of Matilde Serao
}

\section{DARIA VALENTINI}

\begin{abstract}
Summary: Food has long been considered by anthropologists to be an integral part of self-representation, culture, and identity. The present study investigates the early works of Matilde Serao, focusing on food imagery and culinary customs of the city of Naples. Serao's fiction and journalistic production reveal a socio-anthropological approach that emphasizes food's importance within familial and community life. By incorporating documentary and autobiographical elements, the writer offers a unique perspective on the city of Naples and its identity in the late nineteenth century. As we will see, the depiction of food as a socioanthropological construct serves as an effective means to convey important concerns regarding society and history at large, thereby contextualizing Serao's original place within women's writing in Italy.
\end{abstract}

A defining characteristic of the writing of Matilde Serao is her reliance on food imagery and culinary practice within a specific cross-section of Italian society in post-unification Italy, namely the city of Naples. Readers of her works are not soon to forget the passionate and vivid depiction of the manner in which food is consumed and enjoyed, the inventive art of Neapolitan cuisine, and the challenges faced by working class families to put food on the table. Food imagery is essential to the representation of the human experience throughout Serao's works. Her obvious familiarity with food, its preparation and significance for individuals, families, and society at large, endows her fiction with a quality that is unique among the many social realists who preceded her. Among these, Serao looked closely to Zola for inspiration as a chronicler of the human condition at the close of the nineteenth century. ${ }^{1}$ Yet there is equally much that separates Serao from Zola, in particular the emphasis placed on eating as a social rite and as a key element of group identity. The author's portrayal of human interaction

${ }^{1}$ Garzia quotes an article published by Serao in Il Mattino on the occasion of Zola's death (30 Sept. 1902) and concludes: "La Serao nel Naturalismo non vede la 'scuola', ma la realtà del dolore umano, immenso e intenso; e in esso, ammira il senso di pietà per gli umili che aveva già animato l'arte dei romanzieri inglesi e russi dell'Ottocento" (100). 
in each of her elaborate descriptions of food and eating reflects a heightened sociological and anthropological awareness, rather than an explicit political agenda, revealing her original voice in Italian literature.

The study of food by anthropologists has explored the ways in which food is an integral part of human self-representation, culture, and identity. ${ }^{2}$ According to Deborah Lupton, "sharing the act of eating brings people into the same community: they are members of the same food culture. As this suggests, food is instrumental in marking differences between cultures, serving to strengthen group identity" (25). Across different cultures, religious rites often centre on the consumption of food because of its highly symbolic quality. As we will see from the present analysis, Serao's detailed recording of the daily lives of Neapolitans and their eating habits sets them apart from other regions of post-unification Italy and thus contributes greatly to her representation of the city's identity in the final decades of the nineteenth century.

Although her beginnings owe much to verismo, as Salsini has pointed out, Serao's deviation from this tradition is characterized by her rejection of authorial objectivity: "her texts are not detached observations, but perhaps more important for the modern reader, chronicles of lived experiences and, above all, memories" (32). According to Almoia, Serao found her voice as a writer in part through the inner need to document and record genuine life experience (110-12). Additionally, West has highlighted the importance of everyday life in Serao's writing, emphasizing the interplay between autobiographical and documentary elements (1145).

Evidence from Serao's personal correspondence tells us that in her everyday life, writing had to be undertaken alongside many different domestic duties, including that of cooking (in Serao's own words "badare al pranzo in cucina"). ${ }^{3}$ Among numerous examples of her dedication to the chronicling of culinary practices is a fashion column published in $I l$ Mattino dated March 20-21, 1896, in which Serao pays tribute to a popular Neapolitan pastry, le zeppole. ${ }^{4}$ Given her established reputation as a professional woman with an impressive commitment to journalism and literature throughout her nearly fifty year career, these details remind us that

${ }^{2}$ See, for example, Counihan/Van Esterik eds., Food and Culture.

3 Anna Banti quotes this example from a letter written by Serao to Gaetano Bonavenia in 1879 in her introduction to Matilde Serao (L'occhio di Napoli, xi).

${ }^{4}$ Rocco Carbone, 104. Other examples include reviews of banquets for the aristocracy (1900), suggestions for summer drinks (1901), and a description of the custom of drinking afternoon tea (1902). See Carbone, 105-111. 
Serao was also in a position to witness and understand the importance of food in familial and community life in Naples. As I will argue here, Serao's own personal experience as a woman and as a citizen of Naples is undeniably linked to her reliance on food imagery and its importance as a social construct. Further supporting this notion is the writer's use of a descriptive technique that Banti has called "un'esperienza tattile della vita" or a tangible notion of real life (x). Serao thus effectively combines her documentary skill with subjective elements, such as a highly decorative style rich with sensory detail, resulting in literary forms that express her disassociation with scientific positivism. ${ }^{5}$

Serving as a pivotal link between Serao's early career as a journalist and her activity as a novelist is Vita e avventure di Riccardo Joanna, a work focusing on the life of a struggling Neapolitan journalist, Riccardo Joanna. Written in 1887, this novel has important autobiographical elements, especially with regard to the depiction of the main character as a child and a young adult. ${ }^{6}$ Experimenting with her newfound subjectivity, the writer gives voice to what would become some of her most familiar themes in subsequent works: a young child's intellectual curiosity and longing for the mother figure; a fascination with the world of journalism; and the association of food with human comfort and social relationships. In addition to all of these elements, we are treated in Vita e avventure di Riccardo Joanna to elaborate descriptions of meals using precise culinary terms and expressions.

Serao reveals an awareness of the intrinsic link between food and emotions. In the opening chapter, entitled "Piccolo," initial discussions of what to procure and serve for the daily meals are followed by descriptions of the sights and smells of a modest neighbourhood trattoria, where the father and son share many meals. Food becomes a way in which the child communicates and asserts himself within his microcosmic world, on one occasion demanding a whole chicken for lunch, and later revealing the expertise of a gourmand at the table. He inquires about lobster, for example, and exhibits knowledge of other restaurant menu items such as "Charlotte di frutti, la zuppa alla Julienne, vol-au-vents, le scaloppine di Madera” (60). These details are used by the author to delineate the discrepancy between what is desired and what is served: the whole chicken as opposed merely the wing; the sophisticated restaurant fare as opposed to the cheap imita-

5 For more on Serao's collaboration with Fogazzaro on the rejection of positivism as well as naturalism, see Pupino, 333-334.

6 As pointed out by Giglio, Serao adopted the pseudonym of Riccardo Joanna for a brief time before the publication of this novel (12). 
tions thereof that the father and son can afford. Despite any immediate gratification that comes after a meal, the two remain sadly aware of their own incompleteness as a family, as well as the confines of their lower middle class status.

The connection between food and emotion is further elaborated when the protagonist, Riccardo, has left Naples and is seeking to establish himself as a journalist in Rome. The memory of his childhood strongly relies on food imagery, and the trattoria becomes the metaphor for a warm, comforting place filled with human relations and conviviality:

Quando usciva dalla tipografia, come sempre, nell'ora in cui tutte le trattorie fiammeggiano di lumi e sono riboccanti di gente, mentre passeggiava lentamente, per sollevarsi dal lavoro, prima di pranzare, egli dava un profondo sguardo d'invidia alle trattorie dei ricchi, degli uomini felici, che mangiavano delle pietanze delicate in una porcellana elegante: e si rammentava di averle gustate da bambino, quelle dolcezze, nei giorni in cui suo padre aveva denaro, quelle galanterie da palati viziati, il caviale, la ragosta, la pernice, lo storione, la beccaccia, le salse rosse o verdi, colorite gaiamente, piccanti. ${ }^{7}$

Whether real or fictionalized, food represents a link with one's origins. ${ }^{8}$

Moving to a discussion of Serao's best known works, including Il ventre di Napoli (1884), La virtù di Checchina (1884), Il paese di Cuccagna (1891), Suor Giovanna della Croce (1901), and La ballerina (1901), one finds numerous instances of minute descriptive detail centring on domestic tasks, chores, and human survival. A common attribute in all these activities is food, either consumed at home, in the streets, or in one of the many popular and well-attended Neapolitan trattorie. While at times food

7 "When he left the typographer's, as always at the time when the trattorias glow with light and are packed with people, and as he walked slowly to get a break from his work, before lunch, he would glance with envy into the fancy restaurants of happy people eating delicacies out of elegant porcelain dishes: he recalled having tasted them as a child, those exquisite foods, in the days when his father had money, those delicacies for spoiled palates, caviar, lobster, partridge, sturgeon, woodcock, the red and green sauces, spicy and pleasantly colored" (94-95).

8 Anthropologists have underscored the important connection between memory and the emotional dimension of food. See for example Lupton, who writes: "Given that food is an element of the material world, which embodies and organizes our relationships with the past in socially significant ways, the relationship between food preferences and memory may be regarding as symbiotic" (32). 
is used to represent a rite of passage (the baptism in Il paese di Cuccagna), at others it stands as a social signifier between classes, serving to distinguish the everyday from a special event (La virtù di Checchina), or heralding public holidays and festivities (the Carnival in Il paese di Cuccagna, the Easter banquet in Suor Giovanna della Croce). Serao thrives as a chronicler and turns her eye to the simple gestures of arranging a meal, consuming food, or buying it from a street vendor. Thus food becomes a means through which people relate to the world and their environment.

Published as a series of nine articles and then later as a monograph, $I l$ ventre di Napoli takes its title from a statement made by the Italian Prime Minister, Depretis, to describe the conditions of the city of Naples after a devastating cholera epidemic in 1884: "Bisogna sventrare Napoli" (or "Naples must be gutted out." Tench, 289). This image inspired Serao to write a response to the government, and use a metaphor borrowed from one of her most revered literary models, Émile Zola in his famous novel, Le Ventre de Paris. The nine articles paint one of the most colourful portraits ever recorded of the way in which the Neapolitans lived. ${ }^{9}$ Her aim was to raise awareness of the severe limitations of the government's position and the public responsibility to step in rather than judge. In the wake of this human tragedy, what Naples desperately needed, according to Serao, was not to be "degutted," purged, and then left to its own devices, but rather to be rebuilt and endowed with new life. By focusing on human experience in all of its complexity, Serao manages to carry on in Zola's footsteps as a chronicler of human suffering among the working class.

Serao's imagery contains warm, rich colors like those of a carefully selected palette. She combines decorative elements in each of her settings with sketches of random, unassuming figures from the streets of Naples. Serao believed it was important to avoid cliché in portrayals of her city. ${ }^{10}$ In a section of Il ventre di Napoli entitled "Il pittoresco," she dismantles a controversial travelogue on Naples written by Renato Fucini in 1877, in which artists are summoned to claim a specific Neapolitan stereotype as their own:

9 The representation of working class women is a crucial feature of the works of Matilde Serao. For more on this subject see Ursula Fanning, "Women of the Proletariat," 118-129.

10 In her essay "Il pittoresco", Serao condemns the status quo and the glorification of poverty as a subject for vignettes by painters of the late nineteenth century. Serao, Il ventre di Napoli, 158-161. 
Venite, correte o pittori del passato, del presente, e dell'avvenire; calate, calate a sfamarvi o titani dell'arte ai quali manca un soggetto; qui c'è pane per tutti i denti, perché senza uscire dalla città, anzi senza allontanarvi dal centro, troverete e motivi e soggetti da empir tele quante ne fabbrica l'Olanda. ${ }^{11}$

In Fucini's comparison of Naples to Venice, he looks condescendingly at what lies at the foot of Vesuvius: citizens dancing the tarantella, singing and sweating, "povera di tutto, ma ricca di speranze, di giovinezza e di sangue." While the Venetian nourishes himself with "mestizia" and glory, the Neapolitan enjoys maccheroni and sunlight. ${ }^{12}$

Serao turns such images on their heads in her true to life profiles of the Neapolitans. Rather than merely refuting the existence of such stereotypes, she focuses her artistic attention on the mastery of portraiture and still life. Her style, brimming with adjectives and subordination, slows down the progression of actions, allowing images to cascade from line to line and from paragraph to paragraph. Furthermore, much like a skilled film director, Serao creates suspense through the absence of sound when the emphasis is on the visual detail.

Eating is an integral part of the social structure. The simple representation of the daily "pranzo" becomes a metonym for a religious experience, signifying the importance that food has in Serao's prose as a social construct and a ritual, as indicated by the research of Maryse JeulandMeynaud. ${ }^{13}$ Consuming food is seen as form of public activity (Il paese di

11 "Come, hurry, you painters from the past, from the present and the future: come down, descend here and satisfy your appetite, Titans of the arts in search of a subject; here is something for everyone because without leaving the city, even within its center, you will find both motifs and subjects to fill as many canvases as there are in Holland" (14).

12 “....ai piedi del Vesuvio, la voluttuosa e procace Almea balla in ciabatte la tarantella, e canta e suda, povera di tutto, ma ricca di speranze, di giovinezza e di sangue. Quella [Venezia] si nutrisce di mestizia e di gloria; questa di maccheroni e di luce." "... at the feet of Vesuvius, the voluptuous and provocative Almea dances the tarantella in slippers, and sings and sweats, poor in every way, but rich with hope, youth, and life. That [Venice] thrives on melancholy and glory: this survives on pasta and sunlight." Fucini, 16.

13 Jeuland-Meynaud observes Serao's tendency towards the genre of the still life and descriptive exuberance, and concludes that the higher the social status of a character, the least important food appears. She argues that "il nutrirsi appare maggiormente quale rito sociale e spettacolo mondano che quale bisogno primordiale del corpo e rifornimento di energia." See Jeuland-Meynaud, 62. 
Cuccagna), an act of communion with others (Il paese di Cuccagna, La ballerina), or as a performance for the purpose of entertainment (Il paese di Cuccagna, La virtù di Checchina) or spectacle (Suor Giovanna della Croce).

As previously stated, Serao uses subjective experience and memory in her early works to reveal the gap between the living conditions of Naples and those in other parts of post-unification Italy. Sorcinelli suggests that the means of the lower classes at this point in time in the South were so meagre that eating pasta and meat every day was a condition of mythical abundance, a true "land of Cockayne," as it is for one of the characters of Serao's Il paese di Cuccagna (92). Revealing a wealth of anthropological information including folklore, ${ }^{14}$ Serao explains what some of the most commonly eaten foods are and provides elaborate definitions thereof within the text. Her name is often mentioned in manuals that trace the roots of Neapolitan cuisine, due to her demonstrated awareness of culinary customs. ${ }^{15}$ In Il ventre di Napoli, for example, Serao very meticulously records the eating habits of the lower class. In the chapter entitled "Quello che mangiano," she pays homage to the renowned centrepiece of Neapolitan cooking, the pizza. The classification of foods according to their price occupies a large place in this section, resembling a survival manual for those who must ration their pennies in order to satisfy their bellies for the day. As documented here, members of the lower class were so poor that they could not even buy groceries or cook, but instead could only afford scraps of food from innkeepers or low-priced items from street vendors, priced at 1, 2 or 3 "pennies" ("un soldo, due soldi, o tre soldi").

With verve and creativity, the chronicler of this milieu fills paragraph upon paragraph relating how Neapolitans made the most of the little money they had and of the circumstances they were in. Many of her characters, even those belonging to the middle class, like Checchina or Carmela Minino (La ballerina), are always cognizant of their budgetary constraints when putting together a menu or eating out. As we learn in Il ventre di Napoli, for "un soldo" one could opt for a small portion of fried fish, a few fried savory cakes, nine chestnuts, two grilled cobs of corn, or a small portion of spicy, well-dressed zucchini or eggplant to eat with bread. For "due

14 One of the most curious pieces of folklore in Matilde Serao is a tale entitled "Il segreto del mago" in which the origin of the Neapolitan passion for pasta with tomato sauce is cleverly invented. The conclusion of the tale states that the discovery of the dish would bring happiness to the Neapolitans for centuries to come ("ha formato la felicità dei napoletani e nulla indica che non continui a farla nei secoli dei secoli"). See "Il segreto del mago," 109.

15 See for example Teti, 181. 
soldi," the meal could be a coveted plate of pasta, which people would buy from a vendor who cooked it outdoors and covered it with tomato sauce and some cheese. Adding to the folkloric quality of this work, Serao also uses Neapolitan expressions for many of the dishes: the small fried fish are called "fragaglia;" the savoury cakes are "panzerotti;" and the savoury condiment for the bread "scapece."

Furthermore, in Il paese di Cuccagna, Serao not only composes a manual on traditional Neapolitan ice cream making and pastry, such as the popular sfogliatella:

la sfogliatella che si divide in due qualità: la sfogliatella riccia, larga, piatta, sottile, come fatta a scaglie sottili e croccante sotto i denti [....] e la sfogliatella frolla, grassa, grossa e due dita alta, con la pasta che si sfarina, mangiandola, con un fitto strato di crema dentro. ${ }^{16}$

In Il paese di Cuccagna, details regarding food are also interwoven with the theme of the Neapolitan passion for the lottery. As noted by Wanda De Nunzio Schilardi, the obsession with playing the lottery in Serao's novel corresponds to Zola's depiction of excessive drinking in L'Assommoir. ${ }^{17}$ Illustrating this point is the following passage from the chapter entitled "L'estrazione del lotto" in Il paese di Cuccagna, which focuses on the residents of via Santa Chiara at lunchtime:

I mercanti [...] pranzavano, nel fondo delle loro botteghe oscure, sopra un cantuccio di tovaglia macchiata di vino, tenendo, a fianco del largo piatto di maccheroni, la caraffa di vino verdastro, piena di vinello di Marano e chiusa da una foglia di vite accartocciata. I facchini dei mercanti, seduti per terra, sulla soglia della bottega, addentavano lungamente una pagnotta di pane, spartita in due, contenente qualche companatico asprigno, zucchine fritte e immerse nell'aceto, pastinache in salsa brusca, melanzane condite con aceto, pepe e aglio: e l'odore acuto e grasso del

16 "The sfogliatella that can be found in two ways: one called riccia, which is flat and thin, as though it were made of thin layers that are crispy when eaten $[. .$. and the other one called frolla, which is rich, large, as thick as two inches with a pastry that crumbles when eaten with a thick cream filling" (32).

17 De Nunzio Schilardi refers to Zola's L'Assommoir as the primary model for Serao's realism; "Per la Serao questo romanzo è un'opera d'arte ammirabile eletto a modello del suo romanzo più noto Il paese di cuccagna. Se l'alcolismo era la tara sociale intorno cui si muoveva tutto l'intreccio del romanzo zoliano, il gioco del lotto del Paese di cuccagna è la passione fatale che può degenerare in vizio e diventare la rovina morale di un'intera città" 107-108. 
molto pomidoro che condiva tutti quei maccheroni, da un capo all'altro della strada, si univa a quell'odore acuto di aceto aspro e di grossolane spezierie. Da qualche fruttivendolo che ancora passava portando sul capo una cesta di fichi, quasi vuota, o spingendosi innanzi un carrettino le cui ceste contenevano dei fondi di prugne violette, di pesche duracine tutte maculate, i bottegai, i commessi, i facchini, con le labbra ancora rosse di pomodoro o lucide di strutto, contrattavano due soldi di frutta per finire il proprio pranzo. ${ }^{18}$

These lines further exemplify Serao's realistic technique as compared with that of a painter. The reader is faced with an abundance of visual, highly descriptive detail that expresses both immediacy and purpose. Serao uses a color palette that contrasts the redness of the tomatoes and the brightness of the shiny, ripe fruit with the darkness of the merchants' shops and the narrow alleys that surround them. Additionally, she combines visual and olfactory details, like one would expect to find in many of the nineteenth-century realists. The scene above also shows the writer's intent to inform her audience about specific Neapolitan culinary traditions, including a pizza vendor and the indication that pizza and pasta had become the centrepiece of the Neapolitan diet.

Like a living organism, Naples itself is seen as a metaphor for the body and its functions. The city constantly produces waste and its streets never reach a state of cleanliness because every possible human activity occurs there, from laundering clothes, to cooking tomato sauce, to grooming oneself. Food is not only a feature of street life, but also pertains to the representation of women's domestic space. Female characters are often engaged in the tasks of cooking with their servants, buying food, or planning a meal

18 "The shopkeepers [...] were eating over a corner of wine-stained tablecloth at the back of their dark shops, with a greenish glass carafe full of Marano wine, closed by a scrunched-up vine leaf, standing beside a big dish of maccheroni. The porters of the merchants, seated on the ground at the shop entrance, slowly bit off a loaf of bread, which was divided in half so it could hold some sour-tasting viand-fried squash covered in vinegar, parsnips in sour sauce, eggplants seasoned with vinegar, pepper and garlic. From one end of the street to the other, a strong smell of grease came from an overabundance of tomato sauce strewn over all that pasta, which mingled with the acute odor of sour vinegar and crude spices. The shopkeepers, salespersons, and porters, lips still red from the tomatoes or shining with grease, bargained for a pennyworth of fruit to finish their meal with some passing fruit vendor, who carried a nearly empty basket of figs on his head and pushed a barrow with baskets containing purple plums and hard spotted peaches at the bottom" (Il paese di Cuccagna, 3-4). 
with what means they had available. A well-known tale by Serao, La virtù di Checchina, is completely centred on the preparation of a meal for a special occasion. The narration underscores the domestic sphere of women and the kitchen as a place where women relate to each other, sharing everyday tasks and experiences. As is often the case in Serao's fiction, food assumes a symbolic connotation, highlighting its importance as a social marker with the purpose of delineating class differences.

In Serao's fiction, there are sufficient examples of characters from the lower classes for whom food is of utmost importance, mainly because it is scarce. As also noted by Biasin, the contrast between scarcity and abundance serves as an important defining characteristic of the treatment of eating and drinking in fiction (14). Serao's Suor Giovanna della Croce features some of the most noteworthy examples of this contrast. Here Serao describes an Easter dinner organized by the town hall for 300 beggars. These individuals representing the neediest among of Naples' poor enter the dining hall under the scornful eye and false hospitality of the city's upper classes. The novelist skilfully documents the importance of appearance and decorum for the nobility, whose members are impeccably clad in gloves, top hats, and lavish jewels. The humble guests of honour must endure a public humiliation, being served by ladies who can abide neither the smell nor the sight of such human abjection.

Interestingly, and in keeping with key passages from Il paese di Cuccagna, the meal bears the connotation of a religious rite. First of all, women and men are seated on opposite ends of the hall, echoing the manner in which church services were held during Serao's own time. Secondly, the table setting is an immaculate white tablecloth with matching napkins, the shiniest silver, like at the altar. Most significantly, the first items appearing on the table are bread and wine: "Una grossa fetta di pane bianco e fresco era accanto a ogni coperto: una bottiglia di vetro, di poco meno d'un litro, piena di un vinello rosso chiaro, fiancheggiava anche ogni coperto."19 Additionally, Serao employs the technique of intentionally prolonging and slowing down the progression of the meal, in order to achieve a heightened sense of anguish and tension between those of privilege and those with nothing. There is absolutely no enjoyment to speak of in this hall, on either side. The wealthy feel a mixture of fear and disgust; the beggars are torn between the embarrassment of being the object of such a lavish display and the

19 "A large slice of freshly baked white bread was beside every table setting: a glass bottle, slightly less than a liter, filled with a lightly colored red wine, was also placed alongside each table setting" (333). 
intense hunger that they cannot easily control.

As the meal progresses, Serao orchestrates once again a symphony of colors and scents, along with the absence of sound. The dishes of food being served possess a mythical quality reminiscent of a royal banquet:

Ma già, sulle tavole laterali, dove erano solo le tovaglie candide, arrivavano dei piatti, in cui una larga e grossa fetta di timballo di maccheroni fumava, con una crosta ben cotta nel forno, mentre dentro, i maccheroni erano conditi al sugo di carne, rossastri, imbottiti di mozzarelle, di formaggio, d'interiora di pollo. ${ }^{20}$

In its richness and sensual mixture of colors, texture and flavours, this dish stands out as the metaphorical "land of Cockayne" for anyone who has been deprived of food.

The religious connotation of food and its consumption is also evident in Serao's depiction of a simple meal arranged by Caterina and Concetta in $I l$ paese di Cuccagna. Here too there is a prayerful quality to the rite of eating, denoted by the silence, contemplation, and bowed heads during the course of the meal. The sisters concentrate on dividing a large, piping hot plateful of pasta: "le due donne, ogni tanto immergevano la forchetta nei maccheroni lucidi di olio e ne tiravano nel proprio piatto, ricominciando a mangiare." 21 The food is shared like a communion ritual, here like before accompanied by a large, round piece of bread, which they symbolically tear into smaller bits for consumption. The same imagery recurs in La ballerina with another couple of sisters, who enjoy a more elaborate meal of lasagna and meatloaf, but display the same devotion in the slowness and composure of their demeanour, as well as their desire to invite others to partake of their food. ${ }^{22}$

20 "On the side tables, where only white tablecloths appeared, some dishes were being served in which a large portion of timballo was steaming, featuring a crust of well-baked dough. Inside, the pasta was dressed with meat sauce, reddish in color, and filled with mozzarella, cheese and chicken giblets" (Suor Giovanna della Croce, 342).

21 "Every once in a while, the two women stuck their forks into the dish of maccheroni, which glistened with oil, and they took out some for their own plates, beginning once again to eat" (123).

22 "Esse mangiavano lentamente, in silenzio, il loro grasso pranzo napoletano: avevano invitato Checchina Cozzolino, che non aveva portato nulla, seco, a cui nessuno aveva portato niente e che, per superbia, per nascondere la sua orribile povertà, aveva dichiarato seccamente di non avere fame." "They ate slowly, in silence, their greasy Neapolitan meal: they had invited Checchina Cozzolino, who had not brought anything with her, and to whom no one else had brought 
An additional metonymic link between this scene and the charity meal for the beggars is the somewhat primitive demeanour that drives the hungry to satisfy their need for food. Caterina and Concetta chew slowly and intently, moving their jaws up and down like a grazing animal ("un movimento un po' caprigno") and they gnaw on celery stalks with a great contentment. After finishing their supper, both women fall back into the peace and quiet that one might also compare with that of animals that have been sufficiently fed. This primordial instinct is common to all people in one form or another, even to the upper class. When a crowd of well dressed socialites gather in front of an opulent display of desserts in Il paese di Cuccagna, the herd mentality prevails, causing each person to ponder the choices carefully and then take a secure share and eat it in the corner of the room, away from the others. "Alcuni uomini, silenziosamente, seguivano passo passo il cameriere col vassoio, per fare una scelta sapiente, dopo di che si ritiravano in un angolo a mangiare quietamente."23

Serao focuses closely on non-verbal cues, such as body language, both in the scene of the charity meal and in this one. In the former, there is shame on the part of the recipients, indicated by the fidgeting of their bodies. Keeping their glance downward, they are unsure of where to place their hands. Some of them reach for bread without daring to touch it, while others place their hands on their slice for fear that it would be taken away by another guest. But it is in eating the pasta timbale that Serao shows her ability to depict human behaviour in its most basic and varied forms. There are some who swallow the food voraciously, like a hungry beast; others who begin with the filling and move to the pasta, leaving the doughy crust for last; and still others who stash away a piece to take home for a family member-all share the same urgency and desperation that characterize the hungry, and all partake in the same experience. Yet each one differs in his or her clumsiness; the common element remaining is the lack of self-control and a peculiar disconnectedness between the mind and the body. Serao seems intent on exposing contradictions in both physiological and sociological behaviour, such as that between clumsiness and composure, in order to delineate her subject more sharply.

Serao connects eating practices with social norms and rituals. She exposes the behavioural norms of composure and constraint among the upper class citizens in ways that emphasize their eagerness to display self-

anything. Out of pride, to hide her poverty, she had snapped that she was not hungry" (La ballerina, 102).

23 "Some men quietly followed the waiter's tray step by step, so as to make a good choice, after which they went into a corner to eat comfortably" (43). 
control and constraint of instinctual appetites. Not only do the dames attending the supper wear gloves and other formal attire, but they also scornfully impose a code of formality and etiquette on the charity event by insisting on perfectly folded napkins and filled water glasses. By contrast, the physical clumsiness and ignorance of social norms being acted out before the eyes of the privileged classes is like a cruel theatre performance to be watched from above and frowned upon. In fact, food in Serao is an indicator of social status, much like for Zola. Differing from Zola, however, Serao refuses to detach herself from either side, showing empathy for the poor and at the same time enjoying the ceremonies of the middle and upper classes and their formal way of entertaining.

An example of Serao's fondness for social forms of entertainment and festivities can also be found in another chapter of Il paese di Cuccagna, in which Serao depicts a formal reception for the baby daughter of a well-todo pastry shop owner. Even when it is least expected, such as during this party with its vast display of food, a beggar-like figure appears, disrupting the harmonious feelings of satisfaction and well being among the hosts. The description of this gathering has the quality of an exuberant celebration of plenty:

Ai gelati grossi e rotondi come la luna piena, duri da dovervi conficcare profondamente il cucchiaino, di crema alla portoghese, di frutta, di fragola, di caffe bianco, di caffe di Levante, di cioccolatte, si alternavano le formette, gelati più piccoli, più leggieri, formati a sfera, a romboide, a noce di cocco e contenuti graziosamente in certe conchiglie rosse e azzurre di cristallo, dai filetti d'oro: agli spumoni metà crema e metà gelato, di tutte le mescolanze, crema e cioccolatte, mandarino e poncio, crema e pistacchio, crema e fragola, lattemiele e fragola [...].24

This is a land of excess and opulence, which the solitary intrusion of a beggar-like figure ("l'assistito"25) threatens to dismantle with the spectre of

24 "Ices thick and round as a full moon, so hard that the spoon had to be pressed down, followed by thick Portuguese cream, strawberries, white coffee, Levant coffee, chocolate; smaller ices of all shapes, prettily arranged in pink or blue glass shells with gold rims; sponges — half cream and half ice, of all different flavors: chocolate, mandarin, punch, pistachio, strawberries and cream, honey and milk" (41).

25 This enigmatic figure is linked to the superstitions surrounding playing the lottery in Naples. It was believed that the "assistito" would receive the winning numbers in dreams or through supernatural powers. He could not play the numbers himself, but could reveal them to others. 
hunger. "Chi sarà questo straccione?" the hostess asks herself in fear, noticing that his presence disturbs her guests by displaying a lack of physical self-control: "il pezzente devastava il vassoio dei dolci, facendosi intorno ai piedi un circolo di cartine bianche intagliate." $26 \mathrm{He}$ is a silent devourer ("quel divoratore muto") who gets solicitously fed by the host. This character, however, not only underscores the contrast between opulence and indigence, but links food imagery to the widespread, addictive custom of playing the lottery. In Il paese di Cuccagna, Serao shows its devastating consequences on all the layers of Neapolitan society, comparing it metaphorically to a disease that eats away the city's livelihood. The addiction to lottery playing is so extreme and uncontrollable that appears to be as destructive and ominous as the voracity of the "assistito" at the party. In similar fashion, the sense of community and sharing that characterize the life of the city of Naples at large ${ }^{27}$ in the works of Serao is often met with the threat of imminent tragedy or doom.

In the works described above, food serves both as a unifying theme and as a social marker for the Neapolitans. Rather than depicting isolation, Serao conveys the coexistence of different sectors of the population. It has been noted, however, that while Serao shows compassion for the Neapolitans in Il ventre di Napoli, she does not engage in overt social criticism. Her conservatism and ambivalence toward feminism, especially during her marriage to Edoardo Scarfoglio, prevented her from publicly taking a political stance vis-à-vis the deplorable living conditions of the working class (Patriarca, 158-159). Another criticism of Serao alleges that she was unable to denounce the real social causes of poverty, failing to expose the true ideological and political motives that contributed to the state of abjection described in Il ventre di Napoli and Il paese di Cuccagna (Wood, 50-52). Rocco Carbone observes in this regard: "nella Serao, come in Bernari, il trasporto verso un mondo tanto amato, quanto giudicato,

26 "The beggar wreaked havoc with the tray of sweets, dropping a small pile of white candy wrappings at his feet" (53).

27 Serao loves to portray the festive character of Naples both in private gatherings and on public holidays. One instance is the depiction of the Carnival included in Il paese di Cuccagna: "la grande città era data a quell'impetuosa e gioconda fatica, non per amore del lavoro che è causa e conseguenza di benessere, che è in sé fondamento di bontà e decoro; la grande città non si era abbandonata a quella fervente attività, per uno scopo immediatamente civile, miglioramento igienico o industriale, esposizione di arte o di commercio [...] non altro che il carnevale, il carnevale sino all'entusiasmo, il carnevale sino al delirio!" (105-106). 
impedisce la diagnosi scientifica delle colpe e dei mali." 28 Yet Serao's emotional involvement in a world she loved so dearly is also an asset, one that facilitates and sustains her tireless pursuit to capture an authentic social reality in all of its contradictions and complexity. Serao's choice to represent food as a socio-anthropological construct in her prose therefore constitutes an effective means to convey important concerns to her readers. Serao is vocal and indignant yet credible, acting on familiar and collective experience as well as memory in her depiction of life as she knew it, not merely as an independent observer would have seen it. ${ }^{29}$

Thus, despite the known limitations of her position, Serao's anthropological focus on food and human livelihood unveils deeply rooted social realities to an Italian readership largely unfamiliar with Naples. In her treatment of the themes of hunger and indigence, as well as her exposition of the striking contrasts between the poorest and the wealthiest members of Neapolitan society, Serao manages to balance fiction and chronicle in effective prose. She convincingly portrays women in the domestic space, cooking or sharing a meal, and proves their indefatigable skill at supporting one another. Ultimately, the addition of local color through food imagery and folkloric elements endows Serao's writing with a new and genuine form of the pittoresco. The resulting image of the city of Naples is that of a unique and kaleidoscopic organism that depends on collective experience for its own survival.

\section{STONEHILL COLLEge \\ EASTON, MA}

\section{WorKS CiTED}

Almoia, Alba. The Feminine Experience. Carbondale, IL: Southern Illinois University Press, 1996.

Banti, Anna. Matilde Serao. Turin: UTET, 1965.

Biasin, Gian-Paolo. The Flavors of Modernity: Food and the Novel. Princeton: Princeton University Press, 1983.

Counihan, Carole and Penny Van Esterik eds., Food and Culture. A Reader. New York: Routledge, 1997.

28 "In Serao, as in Bernari, rapture for a beloved world, albeit a judged one, impedes the scientific analysis of sins and wrongdoings" (46).

29 As noted by Stewart-Steinberg, Serao wrote Il ventre di Napoli from Rome, taking advantage of this distance to create an image of the city that dismantles stereotypical portraits and employs a critical, dialectical point of view (137). 
Damian, Véronique. L'Eil Gourmand: A Journey through Neapolitan Still Life of the Seventeenth Century. Paris: Galerie Canesso, 2007

De Nunzio Schilardi, Wanda. L'invenzione del reale: studi su Matilde Serao. Bari: Palomar, 2004.

Fanning, Ursula. "Women of the Proletariat: Vistas of Poverty." In Gender Meets Genre: Woman as Subject in the Fictional Universe of Matilde Serao. Dublin and Portland, Oregon: Irish Academic Press, 2002, pp. 118-129.

Francesconi, Jeanne Caròla. La cucina napoletana. Rome: Newton and Campton, 1992.

Fucini, Renato. Napoli a occhio nudo. Turin: Einaudi, 1976.

Giglio, Raffaele. "Introduzione." In Vita e avventure di Riccardo Joanna. Romanzo. Naples: Vecchio Faggio Editore, 1988, pp. 5-23.

Garzia, Raffa. Matilde Serao. Rocca S. Casciano: Cappelli, 1916.

Goddard, V.A. Gender, Family, and Work in Naples. Oxford : Berg, 1996.

Jeuland-Meynaud, Maryse. Immagini, linguaggio e modelli del corpo nell'opera di Matilde Serao. Rome: Edizione dell'Ataneo, 1986.

Lupton, Deborah. Food, the Body and the Self. London : Sage, 1996.

Montesano, Giuseppe. "Il sipario lacerato." In Il ventre di Napoli. Edizione integrale a cura di Patrizia Bianchi. Cava de' Tirreni: Avagliano, 2002, pp. FIN.

Nelson, Brian. "Zola and the Nineteenth Century." In The Cambridge Companion to Zola. Ed. Brian Nelson. New York: Cambridge UP, 2007, pp. 1-19.

Patriarca, Silvana. "Journalists and Essayists, 1850-1915." In A History of Women's Writing in Italy. Eds. Sharon Wood and Letizia Panizza. Cambridge: Cambridge University Press, 2000, pp. 151-163.

Pierre-Gnassounou, Chantal. "Zola and the Art of Fiction." In The Cambridge Companion to Zola. Ed. Brian Nelson. New York: Cambridge University Press, 2007, pp. 86-104.

Polacco, Marina. "Le ambigue virtù di Checchina, ovvero: storia di un'inetta." In La virtù di Checchina. Ed. M. Polacco. Lecce: Piero Manni, 2000, pp. 67124.

Pupino, Angelo R. ed. Matilde Serao. Le opere e i giorni. Naples: Liguori, 2006.

Rocco Carbone, Lorenza. Cara Matilde. Naples: Kairos, 2008.

Salsini, Laura. Gendered Genres. Female Experiences and Narrative Patterns in the Works of Matilde Serao. Madison: Fairleigh Dickinson University Press, 1999. Serao, Matilde. "Il segreto del mago." In Leggende napoletane. Rome: Edoardo Perrino, 1895, pp. 95-109.

- Il paese di Cuccagna. Milan: Garzanti, 1981.

—. Il ventre di Napoli. Ed. Patricia Bianchi. Cava de' Tirreni: Avagliano, 2002.

- La ballerina. Milan: Treves, 1901.

— - La virtù di Checchina. Ed. M. Polacco. Lecce: Piero Manni, 2000.

—. L'occhio di Napoli. Milan: Garzanti, 1962.

_ . Suor Giovanna della Croce. Milan: Treves, 1901.

- Vita e avventure di Riccardo Joanna. Romanzo. Naples: Vecchio Faggio Editore, 1988.

Schehr, Lawrence R. "Deipnomachy, or Cooking with Zola.” Nineteenth-Century 
French Studies 34/3 \& 4 (2006): 338-354.

Sorcinelli, Paolo. "Identification Process at Work: Virtues of the Italian Working Class Diet in the First Half of the Twentieth Century." In Food, Drink, and Identity: Cooking, Eating and Drinking in Europe since the Middle Ages. Ed. Peter Scholliers. New York: Berg, 2001, pp. 81-97.

Stewart-Steinberg, Suzanne. The Pinocchio Effect. On Making Italians, 18601920. Chicago: University of Chicago Press, 2007.

Tench, Darby. "Gutting the Belly of Naples: Metaphor, Metonymy, and the Ausculatory Imperative in Serao's City of Pietà." Annali d'italianistica 7 (1989): 287-300.

Teti, Vito. Il colore del cibo: geografia, mito, e realtà dell'alimentazione mediterranea. Rome: Meltemi, 1999.

West, Rebecca. "Matilde Serao." In Encyclopedia of Continental Women Writers.

Ed. Katharina M. Wilson, vol. 2, pp. 1144-45.

Wood, Sharon. Italian Women's Writing, 1860-1994. London: Athlone, 1995.

Zola, Émile. The Belly of Paris. Trans. Brian Nelson. New York: Oxford University Press, 2007. 
